\title{
From 'Mercenaries' to 'Private Security Contractors': The (Re)Construction of Armed Security Providers in International Legal Discourses
}

Elke Krahmann

Brunel University

\begin{abstract}
The proliferation of armed security contractors in Iraq and Afghanistan has led to widespread criticism of their insufficient control through international laws and conventions. This article suggests that one reason for this omission has been the (re)construction of actors who provide armed force for profit in international legal discourses. During most of the 20th century, armed persons who participated in foreign conflicts for monetary gain were identified as 'mercenaries'. They were outlawed through international legal documents such as the United Nations (UN) Convention on Mercenarism and given restricted rights in the First Additional Protocol to the Geneva Conventions. Today, the same types of actors are increasingly defined as 'private security contractors', and new discourses and international agreements are emerging that attribute to them legality and legitimacy. The aim of this article is to examine the changing legal constructions of armed security providers since the 1970s and the consequences with respect to their control. The article argues that the (re)construction of actors who supply armed force for money in international legal discourses has been made possible by three main discursive strategies: the distinction between persons and corporations providing armed force for profit, the changing focus from the motivations of these actors to their relationship to a 'responsible command', and the shift from a concern about the actors to one about certain activities.
\end{abstract}

*Note for citations: The pagination corresponds with the printed version. 


\section{Introduction}

The discourse on and conceptualisation of actors who supply foreign conflicts with armed force for monetary gain have changed significantly since the formation of Sandline International and Executive Outcomes in the early 1990s. Both firms became quickly known for their involvement in the internal wars of Sierra Leone and Angola because they engaged openly in armed combat. They reminded many observers of the mercenaries of the 1960s and 1970s which had participated in Africa's post-colonial wars. In contrast to mercenaries who had been outlawed in the aftermath of these wars, however, Sandline and Executive Outcomes claimed to be legal businesses, incorporated respectively in the Bahamas and South Africa. Both Sandline and Executive Outcomes disbanded within years as a result of the controversy over their legal status. Nevertheless, since then a new global industry has emerged that has taken over a large range of support functions from Western militaries, such as transport, logistics and maintenance, and also supplies armed security for international military interventions. Despite increasingly supplying services associated with mercenaries - in 2010 the number of armed contractors working for the multinational coalition in Iraq and Afghanistan had risen to over 30,000 and 24,000 , respectively - these persons and their companies have shed the mercenary image. ${ }^{1}$ Although international laws and conventions such as the First Protocol to the Geneva Conventions (1977), the United Nations (UN) International Convention against the Recruitment, Use, Financing and Training of Mercenaries (1989) and the African Union Convention on the Elimination of Mercenarism (1977) all contain prohibitions or restrictions on the hiring of private armed forces and their status in international conflicts, both the industry and the governments that employ them assert the legality of the new 'private military and security companies' (PMSCs). This article uses a discourse-historical approach to examine the (re)construction of international suppliers of armed military and security services in international legal discourses and its implications for their control and regulation. In short, it asks: how have 'mercenaries' become 'PMSCs' and does this explain the perceived weaknesses of international regulations?

Before turning to these questions, it is necessary to understand why the definition of armed security contractors is so controversial and important. When Sandline and Executive Outcomes were founded, most observers were at a loss as to what to call firms that offered combat services in a global marketplace. On the one hand, they fought for profit like mercenaries; on the other hand, they were legally incorporated businesses. A multitude of labels have been invented to describe these firms, including 'private military or mercenary companies', 'private security force', '“mercenary" group' and 'private army'. ${ }^{2}$ Also, in the political sphere the debate over what to call international commercial

1. Dexter Filkins and Scott Shane, 'Afghan Leader Sees Plan to Ban Private Guards', New York Times, 16 August 2010.

2. Herbert Howe, 'Private Security Forces and African Stability: The Case of Executive Outcomes', Journal of Modern African Studies 36, no. 2 (1998): 307; David Francis, 'Mercenary Intervention in Sierra Leone: Providing National Security or International Exploitation?', Third World Quarterly 20, no. 2 (1999): 319; T.K. Adams, 'The New Mercenaries and the Privatization of Conflict', Parameters 29, no. 2 (1999):103-16. 
security providers continues to this day. Even states which employ these firms frequently lack a clear definition and, thus, basis for establishing the legal status or the means of control of these new enterprises. ${ }^{3}$

In the light of these divergences and disagreements, an investigation of the evolution of the mercenary/private military/private security terminology might appear futile or unproductive. However, as legal scholars point out, 'terminology serves important legal and social functions'. ${ }^{4}$ The ongoing debate about the definition of commercial military and security service providers highlights two functions. Firstly, definitions play an important social role in legitimising these firms in the eyes of the public. Whether commercial security suppliers are called mercenaries or private contractors has a major impact on their public perception. Secondly, the definition of commercial military and security service providers is critical for determining their status under international laws and conventions. While in this volume the first function is examined by Berndtsson as well as Schneiker and Joachim, this article analyses the changing international legal discourses and constructions of these actors. To do so, it focuses on the authoritative discourses and definitions of actors which offer armed force in zones of conflict for monetary gain in the two most important international legal texts and treaties in this area: the First Additional Protocol of the Geneva Conventions and the UN Convention on Mercenarism. ${ }^{5}$ The article argues that the discursive (re)construction of commercial security suppliers by the institutions entrusted with the monitoring of these legal conventions, namely the International Committee of the Red Cross (ICRC) and the UN Special Rapporteur and Working Group on the Use of Mercenaries, ${ }^{6}$ helps us understand how a difference has been established between mercenaries and PMSCs that has questioned the applicability of these laws and conventions to armed security contractors operating in contemporary conflicts and interventions such as in Iraq and Afghanistan. This distinction has created a discursive opportunity for the development of new international regulations that endorse the legality and legitimacy of contracted businesses and their employees using armed force in regions of conflict.

To support these arguments, the article first outlines the theoretical difference between the positivist interpretation of international legal categories and their social construction. Contending that the latter can fruitfully be analysed through a discourse-historical approach, the article then addresses the 'How possible?' question by investigating the

3. Elke Krahmann and Cornelius Friesendorf, The Role of Private Security Companies (PSCS) in CSDP Missions and Operations (Brussels: European Parliament, 2011).

4. Keving R. Johnson, "Aliens" and the U.S. Immigration Laws: The Social and Legal Construction of Nonpersons', University of Miami Inter-American Law Review 28, no. 2 (1996-7): 270.

5. The article thus seeks to avoid becoming involved in the argument that contemporary military and security firms are distinct from mercenaries because they, in their majority, provide unarmed support services. The article demonstrates that, even with regard to the commercial provision of armed force, the international legal discourses and definitions of contracted security suppliers have changed. The article also does not differentiate between defensive and offensive force because the definitions of mercenaries in the Geneva Conventions and the UN Convention on Mercenarism lack this distinction, and it has been widely acknowledged that it is impossible to draw a clear line between these two categories in areas of conflict.

6. Please note that these bodies and their discourses are distinct, albeit not entirely separate, from the political discourse, notably within the UN General Assembly. 
historical narratives, discursive strategies and linguistic means that have characterised the (re)construction of actors who supply armed force for money in the authoritative discourses of the ICRC and the UN Special Rapporteur and Working Group on the Use of Mercenaries. The article concludes that the (re)construction of actors who supply armed force for money in international legal discourses has been made possible by three main discursive strategies: the distinction between persons and corporations providing armed force for profit, the changing focus from the motivations of these actors to their relationship to a 'responsible command', and a shift from a concern about the actors to one about certain activities.

\section{Interpretation and Construction}

International laws and conventions, like law in general, are subject to varying interpretations depending on the historical, social and situational contexts to which they are applied. ${ }^{7}$ In fact, the general and abstract nature of international legal texts and concepts requires their interpretation in order for them to be related to real-life cases. According to the 'legal model' of judicial decision-making, the interpretation of legal texts rests on several factors, including (a) the plain meaning of the language contained within a statute, (b) the original intent of the drafters of the statute, (c) the judge's sense of the proper balance of societal interests embodied in the statute, and (d) precedent. ${ }^{8}$ This positivist approach to law embraced by most legal practitioners treats legal concepts as capable of being defined precisely, conclusively and objectively, 'so that for particular operational purposes it should be possible to determine, on the basis of the definition, exactly who does or does not have a particular status, enjoy a particular right, or assume a particular responsibility. ${ }^{9}$

Social constructivist scholarship challenges this view. It notes that legal concepts and their interpretations, such as the notion of indigenous people, gender classifications or the gravity of crimes, are socially constructed. ${ }^{10}$ In contrast to the classical analysis of laws and conventions, social constructivist research suggests that historical, social and ideological contexts play an important role in attributing particular meanings to legal texts. ${ }^{11}$ These meanings go beyond the mere 'translation' of abstract concepts and standards in order to apply them to particular situations and cases. They rather represent the construction or reinforcement of social categories and relationships, including the construction of 'others', the justification of the status quo (or its change) and the legitimisation of certain actions and structures. ${ }^{12}$

7. Nathaniel Berman, 'Privileging Combat? Contemporary Conflict and the Legal Construction of War', Columbia Journal of Transnational Law 43, no. 1 (2004-5): 1-71.

8. Scott Phillips and Ryken Grattet, 'Judicial Rhetoric, Meaning Making, and the Institutionalization of Hate Crime Law', Law \& Society 34, no. 3 (2000): 569.

9. Benedict Kingsburg, “'Indigenous Peoples" in International Law: Constructivist Approach to the Asian Controversy', American Journal of International Law 92, no. 3 (1998): 414; Tey Meadow, '“A Rose Is a Rose": On Producing Legal Gender Classifications', Gender \& Society 24, no. 6 (2010): 817.

10. Paul G. Chevigny, 'From Betrayal to Violence: Dante's Inferno and the Social Construction of Crime', Law and Social Inquiry 26, no. 4 (2001): 787-818; Kingsburg, "Indigenous Peoples" in International Law'; Meadow, '“A Rose Is a Rose"'.

11. Chevigny, 'From Betrayal to Violence', 787.

12. Johnson, “'Aliens" and the U.S. Immigration Laws', 268. 
In addition, constructivist scholarship argues that the interpretation, application and consequences of legal concepts are subject to constant contestation. 'At any given moment, legal rules and categories exist on a continuum from controversial to settled. ${ }^{13}$ The settling or interpretation of legal concepts and texts, therefore, takes a major place in constructivist analysis. It involves two sets of questions. The first set of questions asks who engages in the process of settling legal categories and meanings, and whose interpretation ' $w$ ins' ${ }^{14}$ In Political Science and International Relations this has been addressed, for example, by the theory of framing. ${ }^{15}$ The second question, which is the focus of this article, aims at understanding how particular legal constructions and interpretations in time have been possible. This question has been answered primarily through a variety of discourse analytical approaches. They include investigations of the politico-historical conditions that made the articulation and elaboration of particular statements possible, their place within broader discourses and ideologies, the differentiation between the 'self' and the 'other', and the study of lexico-grammatical, semantic and rhetorical choices in language use, such as the juxtaposition of binaries and extreme case formulation. ${ }^{16}$ For examining the (re)definition of private military and security personnel, the discourse-historical approach developed by Ruth Wodak and others appears particularly suitable. It analyses changing concepts and identities by combining social-historical and linguistic analysis. According to Wodak and colleagues, 'the discourse-historical approach attempts to integrate all available information on the historical background and the original sources in which discursive "events" are embedded. Second, it explores the ways in which particular types and genres of discourse are subject to diachronic change. ${ }^{17}$ Methodologically, the discourse-historical approach employs three tools. The first concerns the interpretive investigation of the ideas and events that have shaped a discourse in the historical narrative. It examines what historical events, ideological contexts and political, social and economic developments are referred to in a particular discourse, and how these references shape its interpretations of concepts and identities. The second tool is the analysis of various strategies used within a discourse. They include constructive strategies which 'serve to "build" and establish particular groups', such as mercenaries or PMSCs; strategies of perpetuation and justification which justify the status quo; strategies of transformation which 'attempt to transform a relatively well-established situation into another of which the speaker or writer may have already formed an image', for example, by referring to 'objectively' changed circumstances; and destructive strategies

13. Phillips and Grattet, 'Judicial Rhetoric', 567.

14. Nick Lynn and Susan Lea, “'A Phantom Menace and the New Apartheid”: The Social Construction of Asylum-Seekers in the United Kingdom', Discourse \& Society 14, no. 4 (2003): 429. See also Annita Lazar and Michelle M. Lazar, 'The Discourse of the New World Order: "Outcasting" the Double Face of Threat', Discourse \& Society 15, no. 2 (2004): 224; Rudolf de Cillia, Marting Reisigl and Ruth Wodak, 'The Discursive Construction of National Identities', Discourse \& Society 10, no. 2 (1999): 155.

15. Roger A. Payne, 'Persuasion, Frames and Norm Construction', European Journal of International Relations 7, no. 1 (2001): 37-61.

16. Lazar and Lazar, 'The Discourse of the New World Order', 225; Lynn and Lea, '“A Phantom Menace and the New Apartheid"', 433.

17. De Cillia et al., 'The Discursive Construction of National Identities', 156; Theo van Leeuwen and Ruth Wodak, 'Legitimizing Immigration Control: A Discourse-Analysis', Discourse Studies 1, no. 1 (1999): 923. 
which 'serve to demolish the existing status quo'. ${ }^{18}$ The third tool is the examination of the linguistic means employed, such as juxtaposition, predication and subject positioning. ${ }^{19}$ Applied to this article, the preceding theoretical considerations suggest that the concept of persons who sell armed force in conflicts has not only been (re)interpreted in traditional legal terms, but also (re)constructed through the linguistic means and the strategic framing of these actors and their services as legal entities and actions within alternative discourses and historical narratives.

\section{The Geneva Conventions}

The First Additional Protocol to the Geneva Conventions, adopted in 1977 and ratified by 171 states to date, has been central to the definition of mercenaries in international laws and conventions. Although the First Additional Protocol does not outlaw mercenarism, it was the first international law document to provide a clear conceptualisation of a mercenary with the purpose of discouraging persons from selling armed force in national and international conflicts for profit. Article 47 of the First Additional Protocol to the Geneva Conventions defines mercenaries by six cumulative characteristics:

\section{A mercenary is any person who}

(a) is specially recruited locally or abroad in order to fight in an armed conflict;

(b) does, in fact, take a direct part in the hostilities;

(c) is motivated to take part in the hostilities essentially by the desire for private gain and, in fact, is promised, by or on behalf of a Party to the conflict, material compensation substantially in excess of that promised or paid to combatants of similar ranks and functions in the armed forces of that Party;

(d) is neither a national of a Party to the conflict nor a resident of territory controlled by a Party to the conflict;

(e) is not a member of the armed forces of a Party to the conflict; and

(f) has not been sent by a State which is not a Party to the conflict on official duty as a member of its armed forces. ${ }^{20}$

In addition, the ICRC, which has been mandated 'to promote and act as guardian' of the Geneva Conventions, ${ }^{21}$ published a commentary which provided an authoritative narrative of the sociohistorical context within which the mercenary clause emerged and how

18. Van Leeuwen and Wodak, 'Legitimizing Immigration Control'.

19. De Cillia et al., 'The Discursive Construction of National Identities', 157; Roxanne Lynn Doty, 'Foreign Policy as Social Construction: A Post-positivist Analysis of U.S. Counterinsurgency Policy in the Philippines', International Studies Quarterly 37, no. 3 (1993): 297-320.

20. 'Protocol Additional to the Geneva Conventions of 12 August 1949, and Relating to the Protection of Victims of International Armed Conflicts (Protocol I)', 8 June 1977, Article 47.

21. ICRC, 'Development of International Humanitarian Law', at: http://www.icrc.org/eng/what-we-do/ other-activities/development-ihl/overview-development-ihl.htm. Last accessed October 25, 2011. 
it should be interpreted. ${ }^{22} \mathrm{~A}$ discourse-historical analysis of the commentary helps us to understand how the ICRC rationalised the emergence of Article 47 and how its particular interpretation of persons offering armed force for money as 'mercenaries' was made possible in the 1970s through distinct discursive and linguistic strategies. Key was the historical contextualisation of the First Additional Protocol's position as a direct response to the 'problem of mercenaries', discussed at the UN during the 1960s, specifically the hiring of armed individuals to fight against national liberation movements or post-colonial governments in Africa. ${ }^{23}$ In the ICRC's narrative, the trigger of this discussion had been the large-scale employment of mostly Belgian, French and South African contracted forces by colonialist powers and business interests in the secession of the resource-rich Katanga region from the newly independent Congo. ${ }^{24}$ According to the ICRC, many African leaders were concerned that these 'mercenaries' could also be used against national liberation and self-determination in their countries, and the UN General Assembly had passed resolutions which considered not only mercenarism a crime but also the mercenaries themselves as criminals. ${ }^{25}$ In short, the historical context of the use of commercially motivated fighters against 'legitimate' wars of independence played a critical role in making possible the definition of mercenaries and the demands for outlawing them in the narrative of the ICRC. Although the draft of the First Additional Protocol submitted by the ICRC did not include any regulations on mercenaries, implying that they would be 'treated like any other categories of combatants and prisoners of war', the framing of the discourse within the context of the Katanga secession experience justified the introduction of a new category of persons into the Geneva Conventions that was neither clearly civilian nor a legitimate combatant. ${ }^{26}$ By introducing this new category of 'mercenaries', the participants sought to deprive such persons of the right to claim combatant or prisoner-of-war status and to make them liable to criminal prosecution for 'acts of violence which would be lawful if performed by a combatant' and 'for the sole fact of having taken a direct part in hostilities'. ${ }^{27}$ Of course, the First Additional Protocol was not the place for a regulation outlawing mercenarism or mercenaries because it was designed to ensure the protection of the victims of international armed conflict. Nevertheless, the ICRC Commentary argued that the proponents of the

22. The authoritative nature of this document was confirmed by its use at the International Criminal Tribunal for Rwanda. See ICRC, 'Summary Report - Direct Participation in Hostilities under International Humanitarian Law' (report of first expert meeting in 2003), undated, 2.

23. 'Protocol Additional to the Geneva Conventions of 12 August 1949, and Relating to the Protection of Victims of International Armed Conflicts (Protocol I)', 8 June 1977 - Commentary, 572.

24. Matthew Hughes, 'Fighting White Rule in Africa: The Central African Federation, Katanga, and the Congo Crisis, 1958-1965', International Historical Review 25, no. 3 (2003): 592-615; Angela McIntyre and Taya Weiss, 'Weak Governments in Search of Strength: Africa's Experience of Mercenaries and Private Military Companies', in From Mercenaries to Market: The Rise and Regulation of Private Military Companies, eds Simon Chesterman and Chia Lehnardt (Oxford: Oxford University Press, 2007), 67-81.

25. 'Protocol Additional to the Geneva Conventions of 12 August 1949, and Relating to the Protection of Victims of International Armed Conflicts (Protocol I)', 8 June 1977 - Commentary, 572.

26. Ibid., 573.

27. Ibid., 575. 
mercenary clause hoped that it would serve as a 'preventative measure' by discouraging people from offering to fight in foreign wars for money. ${ }^{28}$

The discursive strategies employed in the Commentary to legitimise this attempt included two movements. The first was the portrayal of Article 47 as the result of a broad international consensus among the participants of the diplomatic conference leading to the First Additional Protocol. ${ }^{29}$ While the debate was led by Nigeria and other African nations, the Commentary asserted that their views on the need to combat mercenaries were universally shared. The ICRC thus provided important legitimacy for the first conceptualisation of mercenaries and efforts to contain them in international law. The second discursive strategy was the construction of the mercenary as a distinct group of persons with particular characteristics. A central role in this construction was the distinction drawn between the 'mercenary', who 'is essentially motivated by material gain', and the 'volunteer', 'who is moved by a noble ideal'. ${ }^{30}$ Although the ICRC Commentary also mentioned other persons who sold military services, such as 'foreign advisers and military technicians', their absence from the national liberation wars in which the debate was framed made it logical that they were not defined as a specific category and excluded from the definition of mercenaries, 'as long as these experts do not take any direct part in the hostilities'. $^{31}$

Linguistically, the juxtaposition between 'mercenaries' and 'volunteers', and their subject positioning in relation to particular features, served to further justify the exclusion of the former from the protections of the Geneva Conventions. The linguistic construction of the newly defined mercenaries portrayed them as the reprehensible selfish 'other' in contrast to the noble international volunteer. While the text of the First Additional Protocol itself was worded in ostensibly neutral terms, the Commentary noted the importance of distinguishing "between mercenaries pursuing their own "interests" and selfless international volunteers'. ${ }^{32}$ The ICRC explicitly referred to the 'shameful character of mercenary activity' and its 'illegal ends' to explain why they needed to be treated differently. ${ }^{33}$ Moreover, it argued that mercenaries were a danger because they serve the highest bidder who 'will normally be found on the richest side', this being the governments and forces opposed to national liberation movements. ${ }^{34}$ The linguistic constructions of the mercenary also help to explain why Article 47 was understood to mean that being a mercenary was a crime rather than particular activities. ${ }^{35}$ It was the characteristics and aims of the persons who provided conflicts with armed force for profit and not their particular behaviour, such as the excessive use of force, that were presented as objectionable.

The discursive and linguistic framing of 'mercenaries' in opposition to the 'freedom fighter', that is, the international volunteer who supported liberation movements for
28. Ibid., 574
29. Ibid., 574 .
30. Ibid., 579 .
31. Ibid.
32. Ibid., 575, 581 .
33. Ibid., 574.
34. Ibid., 579 .
35. Ibid., 572. 
political and ideological reasons, also entailed major limitations. Since both were usually paid for their services, their motivation became the primary distinguishing factor. ${ }^{36}$ The ICRC Commentary recognised the difficulty of determining personal motivation but concluded that 'no other path was possible' to differentiate between these two actors. ${ }^{37}$ Another limitation of the Commentary's definition of mercenaries justified by the historical narrative was the focus on individuals who provided armed force for money. Although organised groups of 'mercenary companies' had been widespread in Europe between the 14th and 19th centuries, the cases referred to in the ICRC discourse of the 1970s were those of persons recruited individually to fight in African conflicts. ${ }^{38}$

Despite the persistent use of contracted fighters in countries such as the Comoro Islands and disregarding the emergence of new companies such as Executive Outcomes and Sandline International, the official ICRC discourse on mercenaries changed little in the 1980s and 1990s. In its synthesis of international humanitarian law published in 1988, the ICRC only mentioned mercenaries in a single sentence to reiterate that 'mercenaries are not entitled to the status of prisoner of war'. ${ }^{39}$ In 1994 the ICRC's compendium of case studies of international humanitarian law presented only one example which concerned the, somewhat outdated, use of individual 'mercenaries' in liberation conflicts rather than the more contemporary instances of private companies providing combat services. ${ }^{40}$ The compendium repeated the historical narrative used in the 1977 Commentary to the First Additional Protocol, in particular the reference to national independence movements and post-colonial conflicts. It also reiterated the linguistic construction of mercenaries as persons who 'enrol voluntarily out of love of money and a spirit of adventure' and argued that the First Additional Protocol intended to 'discourage mercenaries and augment the risks they run'. ${ }^{41}$ The continued historical construction of mercenaries within the context of liberation movements and the focus on their motivation were considered key reasons for the failure of the First Additional Protocol to be applied during these decades. Although in many cases commercial interests played a major role in the conflicts and in the involvement of foreigners in the fighting, it became the common view that the profit motivation as the single most important criterion identifying a mercenary was impossible to prove in a court of law. This view was expressed in the often-quoted adage that 'any mercenary who cannot exclude himself from this definition deserves to be shot - and his lawyer with him! ${ }^{42}$ All too often, persons who provided armed force for money could claim to be freedom fighters because they were

36. Ibid., 580 .

37. Ibid.

38. Sarah Percy, Mercenaries: The History of a Norm in International Relations (Oxford: Oxford University Press, 2007), 68-93; Janice E. Thomson, 'State Practices, International Norms and the Decline of Mercenarism', International Studies Quarterly 34, no. 1 (1999): 29-30.

39. ICRC, Basic Rules of the Geneva Conventions and Their Additional Protocols (Geneva: ICRC, 1988), 2.

40. ICRC, Compendium of Case Studies of International Humanitarian Law (Geneva: ICRC, 1994), 70, 1412.

41. Ibid., 142.

42. According to Sarah Percy, 'Mercenaries: Strong Norm, Weak Law', International Organization 61, no. 2 (2007): 369, it was first quoted in Geoffrey Best, Humanity in Warfare: The Modern History of the International Law of Armed Conflicts (London: Weidenfeld and Nicolson, 1980). 
involved in internal wars between competing national factions which each claimed to represent the 'people' or legitimately elected governments.

When the proliferation of PMSCs in Iraq and Afghanistan opened up the possibility of overcoming this seeming weakness of the First Additional Protocol, because commercial enterprises are by definition driven by profit, the discourse began to shift. Characteristic of these interventions was that they were not wars of independence, making it difficult for foreign nationals who assisted the multinational coalitions with armed services to claim that they were motivated by ideological reasons. Moreover, public news media provided ample evidence for the superior pay of foreign private security contractors from Western nations in comparison with uniformed soldiers. Accordingly, private security guards in Iraq could earn up to $\$ 200,000$ a year, while US Army Green Berets or Navy SEALs would typically earn only about $\$ 50,000$ in base pay and members of the UK Special Air Service between $f 25,000$ and $£ 80,000 .{ }^{43}$ Contractors openly admitted their profit motivation with quips such as 'When you're talking a possible $\$ 1,000$ a day tax free, it's real attractive'. ${ }^{44}$ It also became apparent that armed 'security contractors' not only shot in self-defence against criminals but also engaged directly in hostilities. In an attack on the Coalition Provisional Authority's headquarters in Iraq, for instance, Blackwater employees fought for several hours with the enemy before they were relieved by US Special Forces. ${ }^{45}$ In Afghanistan, guards contracted to protect support convoys between Kabul and Kandahar were regularly involved in firefights with up to 200 Taliban supporters. $^{46}$

Rather than insisting that the First Additional Protocol be applied to these cases, the ICRC modified its construction of mercenaries. The first indications of this discursive shift could be observed in the ICRC's introduction to international humanitarian law, Constraints on the Waging of War, published in 2001. The volume revised the historical narrative of how Article 47 of the First Additional Protocol had come about, contending that it had been a concession to a group of African states. While the 1977 Commentary stated that the mercenary clause had been agreed by consensus, the authors of Constraints on the Waging of War implied that there had always been a disagreement between African states and the 'West' about it. They thus questioned whether the article had ever had or deserved full international support. Specifically, they asserted that Article 47 'in Western eyes goes against the basic idea that the right to be a prisoner of war ought not to be dependent on the motives, no matter how objectionable, which prompt someone to take part in hostilities' ${ }^{47}$ The publication further challenged the previous interpretation of the Article 47 through linguistic constructions

43. Elke Krahmann, States, Citizens and the Privatization of Security (Cambridge: Cambridge University Press, 2010), 216.

44. Andrew Jacobs and Simon Romero, 'U.S. Workers, Lured by Money and Idealism, Face Iraqi Reality', New York Times, 14 April 2004.

45. Dina Priest, 'Private Guards Repel Attack on U.S. Headquarters', Washington Post, 6 April 2004.

46. Dexter Filkins, 'Convoy Guards in Afghanistan Face Enquiry', New York Times, 6 June 2010; Wikileaks, 2009-9-1.

47. Frits Kalshoven and Liesbeth Zegveld, Constraints on the Waging of War: An Introduction to International Humanitarian Law (Geneva: ICRC, 2001), 90. 
that disparaged its 'disastrous effects', which were fortunately 'neutralised' by the cumulative nature of its definition of mercenaries. ${ }^{48}$

The (re)construction of actors providing armed force for sale focused on the condition that a mercenary 'is not a member of the armed forces of a Party to the conflict'. ${ }^{49}$ This discursive strategy redrew the boundaries of who was considered a mercenary, and who was not, by turning away from profit motivation as the central distinguishing feature. Instead, the emphasis was put on the relationship between foreign persons who were hired for armed services and their employers, be they states or companies. According to Constraints on the Waging of War, Article 47 was an 'exception' which only applied to 'the members of a totally independent mercenary army' not under the command of a party to the conflict. ${ }^{50}$ The publication thus raised serious questions about the applicability of the First Additional Protocol to contractors employed by the coalition forces in Iraq and Afghanistan.

The official ICRC Interpretive Guidance on the Notion of Direct Participation in Hostilities, published in 2009 after five years of consultation with legal experts from governments, the military, academia and international and non-governmental organisations, went even further in its reconstruction of commercial suppliers of armed force. ${ }^{51}$ Tellingly, the document did not use the term 'mercenary' at all, effectively eliminating the category from its discourse. ${ }^{52}$ This was particularly surprising as one of the six cumulative characteristics of mercenaries is their direct participation in hostilities. Clarifying the definition of what is entailed in direct participation in hostilities is thus central to the understanding of who is a mercenary. A justification for the exclusion of mercenarism from the Guidance's consideration was provided by the historical narrative of the Guidance, which contended that wars of national liberation were no longer relevant for the application of the Geneva Conventions. The new historical context comprised 'armed conflicts not of an international character waged between government forces and organized non-State armed groups'. ${ }^{53}$ Moreover, by separating the 'increased outsourcing of previously traditional military functions' from the historical narrative of independence wars, the ICRC presented this phenomenon as an entirely new development not related to mercenarism. ${ }^{54}$ The framing of the issue within a novel historical context was supported by the discursive strategy of creating a new category of actors who were not mentioned in the Geneva Conventions: 'private contractors and civilian employees'. ${ }^{55}$ By omission, the ICRC Guidance implied that private contractors and civilian employees of a party to the armed conflict were distinct from mercenaries, even if they engaged in hostilities. The document thus stated that:

48. Ibid.

49. Ibid.

50. Ibid.

51. There has been a series of reports and articles on this subject in ICRC journals. However, they are not official statements of the ICRC but express the personal opinion of experts.

52. Only one of the consulted experts argued that the Guidance did not sufficiently consider whether private contractors could be regarded as mercenaries. See ICRC, 'Summary Report, Fourth Expert Meeting on the Notion of Direct Participation in Hostilities', Geneva 27/28 November 2006, 34.

53. Ibid., 5 .

54. Ibid.

55. Ibid., 37-40. 
In some cases, however, it may be extremely difficult to determine the civilian or military nature of contractor activity. For example, the line between the defence of military personnel and other military objectives against enemy attacks (direct participation in hostilities) and the protection of those same persons and objects against crime or violence unrelated to the hostilities (law enforcement/defence of self or others) may be thin. ${ }^{56}$

Linguistically, the publication portrayed these 'contractors' as potential victims rather than possible perpetrators of aggression by emphasising that they were civilians 'entitled to protection against direct attack' and exposed to 'increased risk of incidental death or injury'. ${ }^{57}$ Moreover, by describing their services as 'defence' and 'protection', the Guidance gave them a more positive meaning than 'mercenary activity', the term which had been used in $1977 .{ }^{58}$

Like Constraints on the Waging of War, the ICRC Guidance saw little problem with armed contractors participating in hostilities if they had the 'express or tacit authorization of the State party to the conflict'. ${ }^{59}$ With this authorisation they were argued to become members of that state's armed forces under international humanitarian law. In fact, the Guidance further legitimised commercial actors engaging in conflict by suggesting that: 'Theoretically, private military companies could even become independent non-state parties to a non-international armed conflict. ${ }^{, 60}$ This view was first expressed in the Summary Report of the Third Expert Meeting on the Notion of Direct Participation in Hostilities in $2005 .{ }^{61}$ Key to this suggestion was a discursive strategy that distinguished the individual 'mercenary' from the incorporated 'private military companies' by contending that the latter entailed a 'responsible command', one of the criteria for being a legitimate party to a conflict. The Report undermined the linkage between mercenaries and private military companies further by suggesting that 'the financial motivation of private military companies did not disqualify them from being party to a conflict', given that many armed groups were motivated by financial gain and even decisions to join national armed forces were often based on financial considerations. ${ }^{62}$ Of course, by doing so, the Report implied effectively that even the contracted fighters of the 1960s and 1970s who had provided the model for the definition of mercenaries in Article 47 had not in fact been 'mercenaries' because they, too, had acted under some central command or with the authorisation of those who had hired them. Moreover, it eliminated any possibility of anybody ever being classified as a mercenary in accordance with the Geneva Conventions.

In sum, the ICRC discourse not only suggested that (contemporary) armed security contractors were distinct from mercenaries because they were under a responsible command and provided services with a positive connotation such as defence and protection; the changing discourse and linguistic construction also opened up the way for attributing

56. Ibid., 38.

57. Ibid., 37.

58. Ibid., 38 .

59. Ibid., 39, and also footnote 71 .

60. Ibid., 39-40.

61. ICRC, 'Third Expert Meeting on the Notion of Direct Participation in Hostilities, Summary Report', Geneva 23-25 October 2005

62. Ibid., 81 . 
to these incorporated contractors a new legal status under international law by making them a legitimate party to the conflict. The consequence of this changing discourse has been the progressive undermining of the definition and concept of mercenaries in the First Additional Protocol and, thus, its historical efforts to discourage actors from offering armed support in foreign conflicts for profit.

\section{UN Convention on Mercenarism}

The second international legal convention which illustrates the changing discourse on actors who supply conflicts with armed force for money is the UN Convention against the Recruitment, Use, Financing and Training of Mercenaries (signed in 1989, in force since 2001). Although it has only been signed by 10 and ratified by 32 states so far, its global implementation has been monitored by the UN and it has been endorsed repeatedly by the UN General Assembly, illustrating the importance of the convention. ${ }^{63}$ The UN Mercenary Convention emerged within the same historical narrative as the First Additional Protocol, namely the 'use of groups of armed mercenaries against national liberation movements and for the destabilization of the Governments of southern African States', as noted in the documents which preceded the convention. ${ }^{64}$ The UN Convention's definition of mercenaries is thus identical to that of the Geneva Conventions, except that it omits from its concept the requirement that a mercenary does in fact take part in hostilities. The motivation to do so is sufficient to be defined as a mercenary.

\section{A mercenary is any person who:}

(a) Is specially recruited locally or abroad in order to fight in an armed conflict;

(b) Is motivated to take part in the hostilities essentially by the desire for private gain and, in fact, is promised, by or on behalf of a party to the conflict, material compensation substantially in excess of that promised or paid to combatants of similar rank and functions in the armed forces of that party;

(c) Is neither a national of a party to the conflict nor a resident of territory controlled by a party to the conflict;

(d) Is not a member of the armed forces of a party to the conflict; and

(e) Has not been sent by a State which is not a party to the conflict on official duty as a member of its armed forces. ${ }^{65}$

In the light of the historical discourse on national wars of independence which shaped its emergence, the UN Convention adds that:

63. See, for instance, UN General Assembly, 'Resolution Adopted by the General Assembly, Use of Mercenaries as a Means of Violating Human Rights and Impeding the Exercise of the Right of Peoples to Self-Determiniation', A/RES/61/151, 14 February 2007.

64. UN Economic and Social Council, 'Use of Mercenaries as a Means to Violate Human Rights and to Impede the Exercise of the Right of Peoples to Self-Determination', E/RES/1986/43, 1 July 1986.

65. UN General Assembly, 'International Convention against the Recruitment, Use, Financing and Training of Mercenaries', A/RES/44/34, 4 December 1989. 
A mercenary is also any person who, in any other situation: (a) is specially recruited locally or abroad for the purpose of participating in a concerted act of violence aimed at: (i) overthrowing a government or otherwise undermining the constitutional order of a state; or (ii) undermining the territorial integrity of a state. ${ }^{66}$

In contrast to the First Additional Protocol, the UN Convention criminalises both those who use mercenaries and mercenaries themselves. According to Article 2: 'Any person who recruits, uses, finances or trains mercenaries, as defined in article 1 of the present Convention, commits an offence for the purposes of the Convention', and Article 3 states: 'A mercenary, as defined in article 1 of the present Convention, who participates directly in hostilities or in a concerted act of violence, as the case may be, commits an offence for the purposes of the Convention. ${ }^{67}$

The annual reports of Enrique Bernales Ballesteros from Peru, who was appointed as Special Rapporteur in 1987, and those of the Working Group that followed him in 2005, with the mandates to report 'on all further developments on the use of mercenaries, wherever that may occur ... and to make specific recommendations on effective measures to combat the activities of mercenaries', provide detailed insights into the authoritative UN discourse and definitions of persons and companies that offer armed force for private gain. ${ }^{68}$ These reports show that, as late as 1993, Ballesteros still framed the issue of 'professionals of warfare specially recruited to fight in armed conflicts alien to their nationality' within the historical narrative of 'armed conflicts involving the exercise of a people's right to self-determination' ${ }^{69}$ He specifically referred to the involvement of South Africa in Mozambique as the most relevant context of 'mercenary activity ... by third States intervening in an internal armed conflict in order to further their own interests'.$^{70}$ In his discursive construction, Ballesteros defined mercenaries as individual persons who are recruited through special organisations to fight for states or armed groups and who are characterised by personal features such as 'skill and military experience, financial ambition, adventurism, dehumanization and a tendency to identify themselves with ideological options having a predominant authoritarian component'. ${ }^{71}$ Moreover, his reports asserted that the criminal status of mercenaries and those who used them was irrespective of their behaviour, 'whether they are used to carry out or to support military operations, to commit or to repel aggression, for attack or defence or for legitimate or illegitimate causes'. ${ }^{72}$ In short, the UN definition and discourse on mercenaries

66. Ibid, italics added.

67. Ibid.

68. UN Commission on Human Rights, 'The Right of Peoples to Self-Determination and Its Application to Peoples under Colonial or Alien Domination or Foreign Occupation', E/CN.4/1995/29, 21 December 1994. See also UN Commission on Human Rights, 'The Use of Mercenaries as a Means of Violating Human Rights and Impeding the Exercise of the Right of Peoples to Self-Determination', E/CN.4/2005/L.10/ Add.5, 7 April 2005.

69. UN Commission on Human Rights, 'Report on the Question of the Use of Mercenaries as a Means of Violating Human Rights and Impeding the Exercise of the Right of Peoples to Self-Determination, Submitted by Mr. Enrique Bernales Ballesteros (Peru), Special Rapporteur, Pursuant to Commission Resolution 1992/6', E/CN.4/1993/18, 8 January 1993, para. 34.

70. Ibid., para. 41

71. Ibid., para. 34

72. Ibid., para. 35. 
resembled initially that of the ICRC. Armed persons who offered to engage in foreign conflicts for money were framed in the historical context of post-colonial Africa and linguistically described as inhumane and authoritarian in order to justify their criminalisation by the UN Mercenary Convention.

From 1994, however, the UN discourse began to change. In the report of this year, Ballesteros for the first time mentioned Executive Outcomes, which had, allegedly, been hired to protect an Angolan oil refinery but in effect fought alongside National Union for the Total Independence of Angola (UNITA) forces in the local conflict. At that time, Ballesteros clearly categorised the employees of Executive Outcomes as 'mercenaries', thus rationalising their criminalisation under the UN Mercenary Convention. ${ }^{73}$ In 1996 Ballesteros went even further, suggesting that also the company, Executive Outcomes, had committed a criminal offence through its 'recruitment, contracting and training of the mercenaries and the planning of their operations' ${ }^{74}$ In order to legitimise this view Ballesteros referred to the South African authorities, human rights experts and international human rights NGOs whom he had consulted and who reportedly believed that 'Executive Outcomes is a mercenary company which works with mercenaries and carries out mercenary activities'. ${ }^{75}$ However, Ballesteros also noted transformative discourses that challenged these interpretations. For one, Executive Outcomes itself rejected these accusations, claiming that its operation was 'not contrary to internal and international law' ${ }^{76}$ In addition, Ballesteros observed that international attitudes among the UN member states towards the mercenary issue were changing. ${ }^{77}$ Ballesteros admitted that 'gaps and loopholes ... prevent their activities from being classified as mercenary stricto sensu'. ${ }^{78}$ While Ballesteros acknowledged the alternative conceptualisation of actors selling armed force in terms of 'lawful' companies, his own linguistic constructions implied that Executive Outcomes was illegal or at least illegitimate. Defining its personnel as 'paramilitary forces' which 'incorporate mercenaries', he concluded that the company threatened to 'intervene in a country's internal affairs'. ${ }^{79}$

In his 1998 report Ballesteros introduced the term private security companies (PSCs) to describe firms such as Executive Outcomes. The introduction of a new category into the discourse made possible the emerging distinction between persons who provided

73. UN Commission on Human Rights, 'Report on the Question of the Use of Mercenaries as a Means of Violating Human Rights and Impeding the Exercise of the Right of Peoples to Self-Determination, Submitted by Mr. Enrique Bernales Ballesteros, Special Rapporteur, Pursuant to Commission Resolution 1993/5', E/CN.4/1994/23, 14 January 1994, paras. 41, 125.

74. UN Economic and Social Council, 'Report on the Question of the Use of Mercenaries as a Means of Violating Human Rights and Impeding the Exercise of the Right of Peoples to Self-Determination, Submitted by Mr. Enrique Bernales Ballesteros, Special Rapporteur, Pursuant to Commission Resolution 1995/5 and Economic and Social Council Resolution 1995/254', E/CN.4/1996/27, 17 January 1996, para. 64.

75. Ibid., para. 103.

76. Ibid.

77. Ibid., para. 94.

78. UN Commission on Human Rights, 'Report on the Question of the Use of Mercenaries as a Means of Violating Human Rights and Impeding the Exercise of the Right of Peoples to Self-Determination, Submitted by Mr. Enrique Bernales Ballesteros, Special Rapporteur, Pursuant to Commission Resolution 1995/5 and Commission Decision 1996/113', E/CN.4/1997/24, 20 February 1997, para. 92.

79. Ibid., para. 93. 
armed force for money and private companies which did the same. Nevertheless, Ballesteros justified the inclusion of these firms under the UN Mercenary Convention by contending that PSCs were 'nevertheless linked to mercenary activities, as they intervene militarily and for pay'. $^{80}$ According to Ballesteros's narrative, however, his views were no longer shared universally by the UN member states, which rather adopted a 'restrictive approach' to the application of the UN Convention to these new companies and, to his mind, took too little notice of the issue. ${ }^{81}$

By 2000, following visits to the United Kingdom and Cuba, the Rapporteur moderated his critical stance. His construction of PSCs as legal entities with a 'right to work in the area of security' represented a major transformation in his discourse, sustained by a language that recognised their possible 'positive contribution' ${ }^{82}$ In effect, both strategies, the separation of 'PSCs' from 'mercenaries' and the subject positioning of the former in relation to rights and positive characteristics, helped to legalise actors selling armed force in conflict regions so long as they were incorporated businesses. They also rationalised the position that the UN Mercenary Convention did not apply to PSCs and that the international community should 'devise regulations clearly establishing the areas in which private companies may legally operate'. ${ }^{83}$

Despite his changing discourse, Ballesteros seemed not yet ready to accept that the UN Mercenary Convention had no relevance for the new providers of armed force for profit. To support his view, he turned to Article 2 of the Convention, insisting that PSCs must not recruit, hire, finance or use mercenaries to fight in armed conflicts. In addition, his 2001 report began to reframe the issue of mercenarism in terms of the activities rather than the motivations and structures that defined a mercenary. His strategy of advocating the broadening of 'mercenary activity' to include not only 'participation in armed conflicts and attacks against the selfdetermination of peoples' but also 'other illicit activities' served to broaden the remit of the UN Mercenary Convention as it had previously been conceived. Notably, Ballesteros included the 'enlistment in private companies engaged in various activities but which essentially offer security and military assistance services' in his conceptualisation of 'illicit' activities. ${ }^{84}$ Ballesteros also rejected the

80. UN Commission on Human Rights, 'Report on the Question of the Use of Mercenaries as a Means of Violating Human Rights and Impeding the Exercise of the Right of Peoples to Self-Determination, Submitted by Mr. Enrique Bernales Ballesteros, Special Rapporteur, Pursuant to Commission Resolution 1995/5', E/CN.4/1998/31, 27 January 1998, para. 68.

81. UN Economic and Social Council, 'Report on the Question of the Use of Mercenaries as a Means of Violating Human rights and Impeding the Exercise of the Right of Peoples to Self-Determination, Submitted by Mr. Enrique Bernales Ballesteros (Peru), Special Rapporteur, Pursuant to Commission Resolution 1998/6', E/CN.4/1999/11, 19 January 1999, para. 65.

82. UN Economic and Social Council, 'Report on the Question of the Use of Mercenaries as a Means of Violating Human Rights and Impeding the Exercise of the Right of Peoples to Self-Determination, Submitted by Mr. Enrique Bernales Ballesteros, Special Rapporteur, Pursuant to Commission Resolution 1999/3', E/CN.4/2000/14, 9 March 2000, paras 68-9.

83. Ibid., para. 71.

84. Ibid., para. 74. This list was expanded in the 2002 report. See UN Economic and Social Council, 'Report on the Question of the Use of Mercenaries as a Means of Violating Human Rights and Impeding the Exercise of the Right of Peoples to Self-Determination, Submitted by Mr. Enrique Bernales Ballesteros, Special Rapporteur, Pursuant to Commission Resolution 2002/5', E/CN.4/2003/16, 29 November 2002, para. 19. 
argument that had emerged within the ICRC discourse that the command and control relationship between foreign persons who were hired for armed services and contracting states legalised and legitimised them. To him, '[t]he mere fact that it is a Government that recruits mercenaries or hires companies that recruit mercenaries, either in its own defence or to provide reinforcements in armed conflicts, does not make such actions any less illegal or illegitimate'. ${ }^{85}$

While Ballesteros had thus begun to shift the discourse and definition of mercenarism away from the actors, their internal characteristics and their relationships to the parties of a conflict towards the criminalisation of certain 'mercenary activities', including the hiring of mercenaries by PSCs and governments, his replacement in 2004 led to a break in the evolution of the UN mercenary discourse and the largely negative language in which mercenaries and PSCs were constructed. The new Rapporteur, Shaista Shameen from Fiji, 'adopted a pragmatic approach sharply contrasting with her predecessor's long-standing positions'. ${ }^{86}$ In 2005 Shameen issued a joint statement with representatives of the industry which 'strongly recommended that the UN re-examine the relevance of the term mercenary' because 'this derogatory term is completely unacceptable and is too often used to describe fully legal and legitimate companies'. ${ }^{87}$ They obviously recognised the importance of discourse and language in defining actors who supplied armed force for profit. Moreover, their language implied that the UN Mercenary Convention was outdated. The UN Commission on Human Rights was apparently not happy with this and soon replaced Shameen with a working group consisting of five experts from different world regions. The UN Commission on Human Rights' request that the new working group should 'monitor and study the effects of the activities of private companies offering military assistance, consultancy and security services on the international market' left it open whether or not the UN Mercenary Convention could be applied to them. ${ }^{88}$

Given this task, the first report of the Working Group in 2005 identified 'government agreements that provide private military and security companies (PMSCs) and their employees with immunity for human rights violations' as one of its foremost concerns. ${ }^{89}$ However, the Working Group used the term 'PMSCs' from the start and by distinguishing explicitly between mercenaries, mercenary-related activities and the activities of PMSCs its discourse suggested that PMSCs were not mercenaries, and nor were their activities 'mercenary'. In practical terms the Working Group asserted the legality of PMSCs by stating that it 'might consult with private companies or individuals working for those companies', something which would have appeared inappropriate in the case of 'mercenaries'.$^{90}$ Indeed, the second annual report stated that 'there was apparently limited support' for the

85. Ibid., para. 75 .

86. Victor-Yves Ghebali, 'The United Nations and the Dilemma of Outsourcing Peacekeeping Operations', in Private Actors and Security Governance, eds Alan Bryden and Marina Caparini (Zürich: LIT Verlag, 2006), 217.

87. Cited in ibid., 218, emphasis in original.

88. UN Economic and Social Council, 'Report of the Working Group on the Use of Mercenaries as a Means of Violating Human Rights and Impeding the Exercise of the Right of Peoples to Self-Determination', E/ CN.4/2006/11, 23 December 2005, para. 2.

89. Ibid., para. 5 .

90. Ibid., para. 27. 
UN Mercenary Convention among PMSCs, and that '[r]epresentatives of these companies also expressed their conviction that their activities were legal on the basis of having been contracted by Governments and having established corporate structures'. ${ }^{91}$ The discursive strategy of the Working Group to frame PMSCs as separate from mercenaries, and as legal entities which should be authorised to operate through 'a system of registering and licensing', was assisted by a language that humanised the employees of these firms. ${ }^{92}$ Specifically, the report expressed concern and implied confidence that PMSCs recruiting from Latin America and other developing regions should and would respect the rights to security of persons, the rights of workers, national sovereignty and human rights. ${ }^{93}$ Despite noting a range of historical occasions and countries where PMSCs had committed human rights violations and other criminal acts, the second report's insistence that there were PMSCs that worked 'in strict compliance with imperative norms' and 'respect for the principle of the State's monopoly on the use of force' rationalised the notion that PMSCs were unlike the 'shameful' and 'illicit' mercenaries of old. ${ }^{94}$ Only actors 'conducting mercenary activities' should be criminalised. ${ }^{95}$ The report thus followed the discursive reframing of mercenarism and linguistic constructions used already by Ballesteros. While previously the recruitment, use, financing or training of mercenaries, as well as the direct participation of mercenaries in hostilities or acts of violence, had been criminalised, the discursive strategies of the Working Group again shifted the focus towards the prohibition of certain 'mercenary activities'.

Although the Working Group had distinguished between mercenaries and PMSCs from the beginning, the third report published in 2007 presented for the first time a formal definition of PMSCs. Acknowledging the challenges, the Working Group decided to use the term PMSCs 'as including private companies which perform all kinds of security assistance, training, provision and consulting services, including unarmed logistical support, armed security guards, and those involved in defensive or offensive military activities'. ${ }^{96}$ The fact that the definition included armed and unarmed, defensive and offensive services was crucial because this helped it subsume activities previously attributed to mercenaries. Rather than denoting them as 'mercenary activities', the Working Group described them more positively as 'services that are traditionally and characteristically among the core functions and competencies of the State'. ${ }^{97}$ This discursive and linguistic construction also served to reframe the problem as one of the 'delegation' of state

91. UN Economic and Social Council, 'Report of the Working Group on the Use of Mercenaries as a Means of Violating Human Rights and Impeding the Exercise of the Right of Peoples to Self-Determination', EN/CN.4./2006/11/Add.1, 3 March 2006, para. 6.

92. Ibid., paras 37-8.

93. Ibid., paras $27-8$.

94. UN General Assembly, 'Use of Mercenaries as a Means of Violating Human Rights and Impeding the Exercise of the Right of Peoples to Self-Determination', A/61/341, 13 September 2006, para. 94.

95. Ibid.

96. UN General Assembly, 'Implementation of General Assembly Resolution 60/251 of 15 March 2006 Entitled "Human Rights Council", Report of the Working Group on the Use of Mercenaries as a Means of Violating Human Rights and Impeding the Exercise of the Right of Peoples to Self-Determination', A/ HRC/4/42, 7 February 2007, para. 3.

97. Ibid., para. 56 . 
functions. ${ }^{98}$ With regard to the concept of mercenaries, the Working Group concluded that the definition as it currently stands is no longer satisfactory because activities by contracted personnel, whether contracted by the State or intergovernmental organizations, could be caught by the definition which criminalizes private actors engaged in armed conflict' ${ }^{\prime 9}{ }^{\prime}$ In short, even if PMSCs participated directly in armed conflict, the Working Group's discursive strategy determined that they should not be criminalised according to the UN Mercenary Convention. In contrast to Ballesteros, who had accused PMSCs of the crime of hiring 'mercenaries' and of engaging in 'mercenary activities', the Working Group defined neither the contracting of armed persons nor the engagement in violent conflict as mercenary or a crime - at least, if they involved PMSCs. Although the report provided an extensive list of historical examples where PMSCs had operated 'without control, without visibility, without being accountable beyond the company itself, and in complete impunity', these examples did not suffice to require that they should be criminalised once the discursive distinction between mercenaries and PMSCs had helped to establish the view that the companies were legal entities. ${ }^{100}$ Instead, the Working Group concluded that PMSCs should be regulated. ${ }^{101}$

After being tasked by the UN Commission on Human Rights to elaborate such regulative mechanisms in 2008, the Working Group presented an extensive list of possible legal standards, including registration, licensing, accountability mechanisms, vetting, legal and human rights training, and oversight. ${ }^{102}$ In addition, the Working Group proposed that 'National legislation on the industry also should clearly list types of activities prohibited for nationally registered private military and security companies. ${ }^{103}$ Other activities should remain legal but become subject to improved national licensing and regulation. The details of these regulations were set out in the Draft of a Possible Convention on Private Military and Security Companies (PMSCs) for Consideration and Action by the Human Rights Council published in the annex to the 2010 report of the Working Group. ${ }^{104}$

The Draft presented the culmination of the historical narrative, discursive strategies and linguistic constructions that had reconstructed actors who supply foreign conflicts with armed force for monetary gain, with the effect that PMSCs and their employees were excluded from the UN Mercenary Convention. Characteristic of this strategy was the elimination of the term mercenary, whether related to actors or their activities, from the Draft Convention on PMSCs, implying that neither the companies nor their actions had any link to mercenarism. The proclaimed purpose of the Draft Convention to 'regulate the activities of PMSCs and their subcontractors' instead recognised in principle

98. Ibid.

99. Ibid., para. 60.

100. Ibid., para. 31 .

101. Ibid., para. 58.

102. UN General Assembly, 'Report of the Working Group on the Use of Mercenaries as a Means of Violating Human Rights and Impeding the Exercise of the Right of Peoples to Self-Determination', A/HRC/10/14, 21 January 2009, para. 38.

103. Ibid., para. 51.

104. UN General Assembly, 'Report of the Working Group on the Use of Mercenaries as a Means of Violating Human Rights and Impeding the Exercise of the Right of Peoples to Self-Determination', A/HRC/15/25, 2 July 2010, Annex. 
the legality of these firms. ${ }^{105}$ Although Article 8 of the Draft Convention demanded that state parties should take legislative measures to 'prohibit and make illegal the direct participation of PMSCs and their personnel in hostilities, terrorist acts and military actions', these activities were only criminalised if they aimed at or threatened a limited set of outcomes, including overthrowing a government, changing international borders, violating sovereignty and the targeting of civilians. ${ }^{106}$ The Draft thus reduced the scope of the UN Mercenary Convention by suggesting that a separate law was necessary to restrict the operations of PMSCs even when they engaged in what were previously considered 'mercenary activities'. Even the direct participation of PMSCs in hostilities was not considered a criminal act as defined by the UN Mercenary Convention. The Draft Convention rather suggested that the outsourcing of this and other 'inherently state functions' should be prohibited. This discursive strategy put the responsibility for PMSCs engaging in hostilities on the states that hired them rather than the companies themselves. In sum, the Draft Convention revealed the implications of the transformation of the official UN discourse and definition of mercenarism. By eliminating first the concept of mercenaries and second the notion of mercenary activities from its discourse and substituting them with PMSCs and inherently state functions, the Working Group not only undermined the application of the UN Mercenary Convention but also opened up the possibility of legalising persons and companies selling armed force in conflicts for profit through 'improved' state regulation.

\section{Conclusion}

The Geneva Conventions and the UN Convention on Mercenarism provide excellent illustrations of the change in international legal discourses and constructions of actors who sell armed force in conflicts from 'mercenaries' to 'PMSCs'. The preceding analysis demonstrates that distinct discursive and linguistic strategies have been employed by the ICRC and the UN Rapporteur and Working Group on Mercenarism towards achieving this outcome. In the case of the ICRC, the changing historical context characterised by the proliferation of incorporated companies providing military and security services to Western states engaged in international interventions in Iraq and Afghanistan facilitated the legal and discursive reconstruction of the definition of 'mercenaries' from a focus on the profit motive to their (alleged) lack of a unified or responsible command. Persons offering armed security services were no longer constructed in opposition to international volunteers in liberation movements, but in terms of their inclusion in a corporate structure and their relationship to the Western states conducting international interventions. The discourse suggested that so long as these persons could claim to be part of a clear command structure, whether that of a company or of the states involved in the conflict, they could not be mercenaries. In linguistic terms, this reconstruction went hand in hand with the change from 'mercenaries' to 'private contractors' and 'private military companies'. While the former had been denoted as selfish and their activities as illegal and shameful, the latter were described as members of a 'responsible force'

105. Ibid., p. 24.

106. Ibid., p. 28. 
which provided 'defence' and 'protection'. The strategy employed by the ICRC served to eliminate 'mercenary' as a linguistic and legal category. By progressively eradicating the term 'mercenaries' from its discourse and replacing it with 'private contractors', the ICRC achieved the linguistic reconstruction of the contracted person employing armed force in conflicts. It also substituted the negative image and adjectives that adhered to the mercenary with connotations of legality and legitimacy.

The main feature of the UN discourse, by contrast, has been a shift in the definition of mercenarism from a focus on the agents to a focus on specific activities. In the early 1990s Special Rapporteur Ballesteros suggested that being a mercenary was a crime due to the negative characteristics of mercenaries such as profit motivation, adventurism and authoritarian views. He contended that mercenaries should be prohibited, irrespective of whether they engaged in hostile actions. However, over the succeeding years Ballesteros noted that the views of the international community of states with respect to PMSCs were very different from those on persons who had previously been considered mercenaries, and that he could find little support for his belief that these firms presented a new form of mercenarism. By 2000 he conceded that PMSCs were legal entities distinct from mercenaries, and his discursive strategy focused on the possibility of expanding the range of services which could be considered 'mercenary activities' and thus prohibited under the UN Mercenary Convention. The Working Group which followed him took up this idea, but this led the members to further question the applicability of the UN Mercenary Convention. The broad definition of PMSCs adopted by the Working Group, which included firms providing armed and unarmed, offensive and defensive, contributed to the elimination of the term 'mercenaries' from its reports because it implied that, irrespective of their motives or actions, PMSCs were not mercenaries. The Working Group also replaced the concept of 'mercenary activities' with more neutral or positive terms such as 'inherently state functions'. This linguistic change made it possible to increasingly delimit the types of actors and services that should be criminalised. The UN Draft Convention on PMSCS published in 2010 drew the seemingly logical conclusion from this changing discourse by suggesting that even the direct participation of PMSCs in hostilities should only be prohibited in a limited set of circumstances. Instead, it proposed the regulation and licensing of these firms and their services.

In conclusion, both discourses show how it has been possible to shift the historical, linguistic and legal conceptualisation of actors offering armed force for money in zones of conflict from mercenaries to PMSCs. In addition to the common distinction between individuals and corporations providing armed services for profit, they demonstrate two distinct discursive strategies. One strategy has been the reconstruction of the person and his or her relationship with a 'responsible command'; the other has been the shift from the actor to certain illegal activities. In the end, these discursive changes have resulted in the same outcome. They have justified why the two most important international legal documents on mercenarism have not been applied to PMSCs operating in contemporary conflicts, and they have created a discursive space for the legalisation of the use of armed force by actors who are essentially motivated by profit. 